DOI: $10.21554 / \mathrm{hrr} .091908$

\title{
STATUS AND PERSPECTIVES OF WAR CRIMES PROCESSING IN BOSNIA AND HERZEGOVINA
}

\author{
Dževad Mahmutović ${ }^{1}$ \\ Mirna Alibegović
}

Faculty of Law, University of Tuzla, Bosnia and Herzegovina
Original scientific paper

Received: $2019 / 6 / 18$

Accepted: 2019/9/5

\begin{abstract}
Serious, systematic and massive violations of international humanitarian law were committed during the 1992-1995 armed conflict in the territory of Bosnia and Herzegovina. The criminal prosecution and prosecution of perpetrators of these violations of international humanitarian law falls within the jurisdiction of several courts of various levels, namely the ICTY, the courts in Bosnia and Herzegovina, as well as the courts of other countries, in accordance with the principle of universal jurisdiction. However, the fact that is justifiably worrying is that, even after 24 years since the end of the war, the work on prosecuting those responsible for violations of international humanitarian law in Bosnia and Herzegovina is nowhere near completion. This is a consequence of non-compliance with the guidelines of the National War Crimes Processing Strategy, implementation of various laws at the state and entity levels, as well as limited regional cooperation and dialogue. The results of the research show that the concerns and perceptions expressed by citizens, as well as by some domestic and international institutions regarding the effectiveness of prosecutors' offices in prosecuting war crimes cases are very justified. Such data call for action by all relevant individuals and institutions to undertake activities in their own domain in order to advance this process and bring it to the level it deserves, given the importance for the overall BiH society.
\end{abstract}

Key words: war crime, genocide, International Criminal Tribunal for the former Yugoslavia.

\section{INTRODUCTION}

\section{General review of war crimes processing in $\mathrm{BiH}$}

During the 1992-1995 armed conflict on the territory of Bosnia and Herzegovina, serious, systematic and mass violations of international humanitarian law were committed, resulting in various serious violations of fundamental human rights and freedoms. Although the United

\section{'Correspodence to:}

Dževad Mahmutović, LL.D, Faculty of Law, University of Tuzla, Bosnia and Herzegovina

Muhameda Hevaije Uskufije 7, 75000 Tuzla, Bosnia and Herzegovina

Phone:+38761804941

E-mail: dzevad.mahmutovic@untz.ba
Nations Human Rights Council (UNHRC) (2008) has taken a stand that the international community has a priority to "recognize the right of victims of gross violations of human rights and serious violations of international humanitarian law, and their families and society as a whole, to know the truth regarding such violations, to the fullest extent practicable", the consequences of this conflict have not yet been determined with certainty. ${ }^{2}$

${ }^{2}$ On the consequences of violations of human rights and freedoms during the war in $\mathrm{BiH}$ (1992-1995). See more: Tabeau, E (2009) Conflict in numbers: Casulties ofthe 1990s Wars in the former Yugoslavia (1991-1999), Helsinki Comittee for Human Rights in Serbia, Belgrade and The Research and Documentation Center in Sarajevo (RDC) (2019) Human Losses 1991-1995 (20 May 2019). Available from: http://www.idc.org.ba/index.php?option=com_content\&view $=$ section\&id=35\&Itemid=126\&lang $=$ bs,

Kukić, S et al. (2019) Sistem ranog upozoravanja specijalno izdanje - Pravda i istina u BiH iz perspektive javnosti (15 april 2019). Available from: www.undp.ba/download.aspx?id=355 and Mahmutović, Dž (2011) Ratni zločini u Bosni i Hercegovini - Kažnjavanje i reparacija-doctoral thesis, University of Tuzla, Tuzla, pp. 13-20. 
It is justified to fear that the true scale of these crimes ${ }^{3}$ will never be known.

It is evident that, with brutality and scale, these crimes outweigh all crimes committed after World War II.

In response to the multiple and systemic crimes and violations of fundamental rights, a number of measures have been developed worldwide, including the prosecution of the perpetrators of these crimes. These measures, especially the prosecution of criminals, also play an important role in responding to crimes committed in $\mathrm{BiH}$.

With the reform of the criminal legislation in 2003, $\mathrm{BiH}$ took significant measures, first and foremost, in the substantive and procedural standardization of the prosecution of war crimes committed. The Criminal Code enacted within this reform, in accordance with international standards, in Chapter 8 incrminates Crimes against humanity and values protected by international law. ${ }^{4}$

Chapter Eight of the Criminal Code of Bosnia and Herzegovina predicts criminal offences whose incrimination is rooted in international conventions and violations of war and humanitarian law, which protect humanity and other values protected by international law.
These are: Genocide (Article 171); Crimes against humanity (Article 172); War crimes against civilians (Article 173); War crime against the wounded and the sick (Article 174); War crimes against prisoners of war (Article 175); Organizing a group of people and instigating the perpertration of genocide,crimes against humanity and war crimes (Article 176); Unlawful killing or wounding of the enemy (Article 177); Marauding the killed and wounded at the battlefield (Article 178); Violatig the Laws and Practices of Warfare (Article 179). ${ }^{5}$

War crimes processing has multiple goals: truth-finding, prevention of repetition (deterrance), punishment of perpetrators, reconciliation between perpetrators and victims, promotion of the rule of law, separation of individual from collective responsibility, etc (Thoms, Ron, \& Paris, 2010). Considering the above and the importance of war crimes processes in $\mathrm{BiH}$ when it comes to building trust among people and preventing new conflicts, it can be concluded that the burden is on the criminal proceeding entities involved in processing war crimes.

Criminal prosecution and processing of war crimes committed in the territory of Bosnia and Herzegovina has been and is under the jurisdiction of several courts of different levels, namely: the International Criminal Tribunal for the former Yugoslavia (hereinafter: the ICTY), the courts in $\mathrm{BiH}$, and the courts of other countries, in accordance with the principle of universal jurisdiction (Ivanišević, 2008).

\footnotetext{
${ }^{5}$ About the specific and common characteristics of these offenses see more: Tomic, Z (2003) Krivično pravo II (posebni dio), Faculty of Law, Sarajevo, pp. 413-416, Đurđić, V and Jovaševic, D (2003) Međunarodno krivično pravo, Nomos, Belgrade, pp. 74-76, Mrvić-Petrović, N (2008) Krivično pravo-opšti i posebni deo (peto izdanje), Union University, Faculty of Law, Belgrade, pp. 338-340, Babić, M and Marković, I (2007) Krivično pravo - posebni dio (drugo modifikovano izdanje), Faculty of Law, Banja Luka, pp. 354-356, Babić, M et al. (2005) Komentari krivičnog/kaznenog zakona BiH, CE/EC, Sarajevo, pp. 557-558; Mahmutović, Dž op.cit., pp. 43-71, Degan, VĐ, Pavišić, B and Beširević, V (2011) Međunarodno i transnacionalno krivično pravo, Union Univrsity, Faculty of Law, Belgrade, Official Gazette (2011) Comments of the Criminal Code of the Socialist Federal Republic of Yugoslavia (1978) Savremena administracija, Belgrade, Karović, S year 21st. (2012) Kaznena djela protiv čovječnosti i međunarodnog prava Polic. sigur., Zagreb, No. 4, pp. 790-799, Marković, I (2010) Zločin protiv čovječnosti u Krivičnom zakonu Bosne i Hercegovine, Annual of the Faculty of Law of University of Banja Luka, Banja Luka, No. 31/32, Josipović, I (2007) Ratni zločini - Priručnik za praćenje suđenja, Center for peace, nonviolence and human rights, Osijek.
} 
The inertia of domestic judicial authorities in responding to ongoing crimes has forced the international community to react. As early as May (25) 1993, UN Security Council adopted Resolution 827 , establishing the ICTY, whose responsibility was to prosecute persons responisble for serious violations of internationalhumanitarian law, under individual or command responsibility ${ }^{6}$, executed in the territory of the former Socialist Federal Republic of Yugoslavia (hereinafter: the SFRY), beginning in 1991 (Jovašević, 2004, p. 361).

According to the latest official data, 161 persons have been indicted for grave violations of international humanitarian law, and so far, 109 cases have been finalized, 90 of which have resulted in convictions and 18 have been found not guilty. In relation to the remaining number of accused, it is important to emphasize that in relation to 20 persons the indictment was withdrawn, while 17 accused died before or after transfer to the ICTY. Under the Rule 11 bis, 13 cases were reffered to national courts, and before Mechanism for International Criminal Tribunals ${ }^{7}$, there is currently one appeal and one retrial ${ }^{8}$.

Of the lasting contributions made by the ICTY to international justice, it is certainly most important to emphasize the fact that this court has held all persons accountable, regardless of their position. The individualization of guilt is a great achievement in the work of this court, as it prevents entire communities from being called "collectively responsible".

${ }^{6}$ See more: Popović, D (2009) Vodič kroz tranzicijsku pravdu u Bosni i Hrcegovini, UN Development program, Sarajevo.

${ }^{7}$ The Residual Mechanism was established by the Resolution 1966 (S/RES/1966), adopted by the Security Council at its 6463th session, on 22 December 2010. Available from: http:// www.icty.org/x/file/About/Reports\%20and\%20Publications/ ResidualMechanism/101222_sc_res1966_residualmechanism bcs.pdf). UN Security Council Resolution No. 1966, states that "the functions and scope of the Mechanism will gradually diminish, with fewer employees having relatively reduced functions." The Security Council has decided that the remaining accused who are on the run, 2 appeals, 3 retrials, 4 trials in the Mechanism cases will continue to act until the Council decides otherwise, but further states that progress in the Mechanism's work will be reviewed in 2016 and every two years thereafter.

${ }^{8} \mathrm{An}$ appeal is pending in the case against indictee Ratko Mladić (MICT-13-56). On 15 December 2015, the ICTY Appeals Chamber ordered the retrial of Jovica Stanišić and Franko Simatović (MICT-15-96) on all counts, and the trial before the Mechanism began on 13 June 2017. See more at: http://www.irmct.org/bcs/ cases [24 April 2019].
Listening to a large number of eyewitnesses and victims of the events, the ICTY has identified key historical facts regarding the crimes committed in this area, contributing substantially to the real inability to deny the crimes. By cooperating with national prosecutors' offices and courts in the region, passing on evidence and case law, as well as contributing to the creation of specialized war crimes tribunals, the ICTY has also made a significant contribution to strengthening the rule of law and achieving justice for victims at lower levels (Žagar, 2013). The transfer of burden to national courts can only be successful if local prosecutors have the will and the means to effectively prosecute those cases, and if the courts act independently and in accordance with international fair trial standards (OSCE, 2013).

Despite its contribution, the ICTY has received numerous criticisms, which, given the nature of the argument, can be categorized into three groups: legal criticisms, which relate both to the legality of the court and to the rules governing its proceedings and the case-law itself, then criticisms of a political nature, concerning the policy of the Prosecution, i.e. the manner in which the persons indicted were "selected", and ultimately criticisms from a psychological-criminological point of view, aiming at evaluating the court 's contribution to some higher goals, such as reconciliation and prevention of future conflicts (Dimitrijević, Hadži-Vidanović, Jovanović, Marković, \& Milanović, 2013).

During and shortly after the 1992-1995 armed conflict, the judiciary in $\mathrm{BiH}$ prosecuted war crimes cases alongside the International Criminal Tribunal for the former Yugoslavia.

The prosecution of war crimes in $\mathrm{BiH}$ continued after the end of the war, until 2003, at the entity level, before 10 cantonal and 28 municipal courts in the $\mathrm{FBiH}$ and five district and 19 basic courts in RS (Mahmutović, 2011, p. 103).

Thereafter, the prosecution of war crimes also falls within the jurisdiction of the Court of $\mathrm{BiH}$. The Court of $\mathrm{BiH}$, based in Sarajevo, is established in 2000 in order to ensure the effective exercises of the competences of the State of Bosnia and Herzegovina and the rule of law in the territory of this state?

The War Crimes Chamber of the Court of Bosnia and Herzegovina was formed with the aim of continuing the prosecution of war crimes even after the ICTY ceased to operate.

${ }^{9}$ Law on the Court of BiH (consolidated text), Official Gazette of BiH No. 49/09, Article 1. 
Considering that in the past war, a large number of war crimes have been committed in $\mathrm{BiH}$ and that a large number of persons appear as possible perpetrators, and that the Court will not be able to prosecute them all, certain criteria have been drawn up, according to which all subjects will be evaluated and assesed.

First, it was agreed that cases which, after evaluation are designated as "sensitive" shall be prosecuted before cantonal or district courts, and cases that are assessed as "very sensitive" shall be tried before the War Crime Chamber of the Court of Bosnia and Herzegovina. ${ }^{10}$

As of 2018, a total of 205 cases were finalized by Section I for War Crimes of the Court of $\mathrm{BiH}$, in which 217 men and 5 women were finally sentenced, while 106 men were finally released. For war crimes committed, this Court has so far imposed 2,748 years in prison. ${ }^{11}$

In addition to the ICTY and national courts, the prosecution and processing of perpetrators of war crimes committed in the period 1991-1995 also took place before courts of other jurisdictions, in accordance with the principle of universal jurisdiction. ${ }^{12}$

Significant war crimes trials in $\mathrm{BiH}$, conducted on the principle of universal jurisdiction, are the case against Nikola Jorgić for crimes committed against Bosniaks in 1992, in the wider Doboj Municipality ${ }^{13}$, against Maksim Sokolović14 ${ }^{14}$, against Đurađ Kušljić. ${ }^{15}$

\footnotetext{
${ }^{10}$ See more: Jelačić, N et al., op.cit., pp. 8, 9 and Škorić, M (2005) Mješoviti međunarodni kazneni sudovi, Collection of works of the Faculty of Law of the University of Rijeka, Rijeka, No. 2, pp. 933970.
}

${ }^{11}$ See more: http://www.sudbih.gov.ba/stranica/102/pregled [20 June 2019].

${ }^{12}$ See more: Novoselec, P (2003) Temeljne crte novele Kaznenog zakona, Hrvatski ljetopis za kazneno pravo i praksu, Zagreb, Vol. 10, No. 2/2003, p. 104, Seizović, Z (2008) Međunarodno javno pravozbirka eseja, University of Zenica, Zenica, pp. 203, Simović-Hiber, I (2007) Sistem rasprava o ideji vladavine prava, osnovama krivičnog zakona, pojmu zločinacke grupe i internacionalizaciji krivičnog pra$v a$, Institute of Criminological and Sociological Research, Belgrade, pp.

${ }^{13}$ See more: Urteil Oberlandesgericht Düsseldorf (Nikola Jorgic) IV-26/96 (26 September 1997). Available from: http://www.haguejusticeportal.net/Docs/NLP/Germany/Jorgic Urteil 26-9-1997. pdf [9 May 2019], Bundesverfassungsgericht Düsseldorf, Beschluss vom 12. Dezember 2000, (Nikola Jorgic). Available from: https://www.bundesverfassungsgericht.de/entscheidungen/ rk20001212_2bvr129099.html [9 May 2019], European Court of Human Rights, Jorgic vs. Germany (Application no. 74613/01), Judgement, Strasbourg, 12 July 2007. Available from: http://invisiblecollege.weblog.leidenuniv. nl/files/2007/07/jorgic\%5B1\%5D.pdf [9 May 2019].

${ }^{14}$ Final Judgment of the Higher Regional Court at Düsseldorf v. Maksim Sokolović, No. 3StR 372/00 from 21 February 2001.

${ }^{15}$ Judgment of the Bavarian Higher Regional Court, No: 3 StR 244/00 from 15 December 1999 and Decision of the Federal Court of Justice, No: 3 StR 244/00 from 21 February 2001.
In this particular case, universal jurisdiction, that is, the actions of other states against war criminals, contributed not only to fulfilling the international community's obligation to prosecute some of the most serious and cruel crimes, but also to raising Europe's awareness of crimes committed on the soil of Bosnia and Herzegovina, through determination of judicial facts.

The current situation and perspectives in the area of prosecuting crimes in $\mathrm{BiH}$ are the subject of this research, and the starting hypothesis is that the response of competent $\mathrm{BiH}$ institutions is not appropriate to the volume and gravity of the crimes committed. This research will first analyze the challenges faced by the $\mathrm{BiH}$ judiciary in the prosecution of war crimes, and by empirical research we will determine the adequacy of the response of the competent $\mathrm{BiH}$ authorities.

\section{Challenges in War Crimes Processing in $\mathrm{BiH}$}

In order to ensure the continued fight against impunity and the achievement of justice for war crime victims, it is necessary to identify the most significant challenges, or obstacles, that have hindered the effective prosecution of those responsible for war crimes. Among those are especially emphasized: pluralism of applicable laws and the issue of retroactive application of laws; work on "Category A" cases; interpretation and application of "complexity criteria"; and regional dialogue and cooperation.

\section{Pluralism of applicable laws and the issue of retroactive application of laws}

The non-harmonized application of the laws in force in Bosnia and Herzegovina, one of the biggest challenges in the prosecution of war crimes and often leads to distortion of the rule of law and the principle of equality in the process,as well as generally inconsistent penal policy in the field of war crimes processing. 
Moreover,the application of differentcriminal laws has resulted in significant differences in the legth of sentences, as a sanction, that are pronounced for war crimes by the Entity Courts compared to the Court of BiH. ${ }^{16}$ In addition, the principle that, in practice, produced the most controversy is certainly the issue of retroactive application of the more lenient law (lex mitior).

The judgement of the Appelate Division of the Court of Bosnia and Herzegovina, No. Kpž 32/05 from 4 April 2006 was the firstlegally binding verdict for the offences under the Chapter 8 of the Criminal Code of Bosnia and Herzegovina. With the above judgment, the accused Abduladhim Maktouf was found guilty of the criminal offense of War Crimes against Civilians under Article 173 (1) (e) in conjunction with Article 31 of the Criminal Code of Bosnia and Herzegovina was sentenced to five years in prison by the application of the sentence mitigation provisions. ${ }^{17}$ Furthermore, by Judgment of the Court of BiH, No. X-KRŽ-05/107 of 19 November 2007; The Accused Goran Damjanović was found guilty of the criminal offense of War Crimes against Civilians referred to in Article 173 (1) (c) in conjunction with Article 180 (1) of the Criminal Code of $\mathrm{BiH}$, and was sentenced to 11 years in prison.

\footnotetext{
${ }^{16}$ In a 2011 report, the OSCE concluded that the implementation of various criminal laws at the state and entity levels can be problematic in certain types of war crimes cases:" It is certainly acceptable that the question of what criminal law should be applied to war crimes cases is assessed on a case-by-case basis. In many cases before the Entity Courts, the application of the [1976] Act is not a serious problem in practice. Generally, cases where the application of different laws undermines the principle of equality before the law are those in which a court, by applying the [2003] Act, can sentence an accused to imprisonment longer than a sentence of 15 to 20 years, which is the maximum sentence prescribed by the Act [from 1976]. In these cases, the application of the [1976] Act clearly does not allow the court to impose a sentence commensurate with the gravity of the crime. Nor are the penalties in these cases consistent with national practice. Another category of cases where the application of the [1976] Law is problematic is that in which the defendant's conduct is best described in accordance with the concept of crimes against humanity or the theory of command responsibility, which are expressly prescribed only by the Act [from 2003]." (See more: OSCE (2011) Achieving Justice in Bosnia and Herzegovina: Prosecution of War Crimes Cases 2005-2010).

${ }^{17}$ In this judgment, the Court took the legal view that Article 4a) of the $\mathrm{CC}$ of $\mathrm{BiH}$ “... has, in its entirety, taken over into the criminal justice system of $\mathrm{BiH}$ the provision of Article 7, paragraph 2 of the European Convention, which allows for an exceptional departure from the principles of Article 4 of the Criminal Code of $\mathrm{BiH}$, as well as the derogation from the mandatory application of a more lenient law in proceedings that constitute criminal offenses under international law. (See more: Court of BiH, Maktouf, Case No. Kpž-32/05, First Instance Verdict, 04/04/2006, Available from: file: ///C:/Users/ Mirna/Downloads/K3205_1K_MA_drugostupanjska_04_04_2006. pdf).
}

After the judgment became final, Abduladhim Maktouf appealed to the Constitutional Court of $\mathrm{BiH}$ on 19 June 2006, complaining that, in impugned judgment, the rights guaranteed by Article II/ 4 of the Constitution of Bosnia and Herzegovina, as well as Articles 7 and 14 of the European Convention for the Protection of Human Rights and Fundamental Freedoms (European Convention) were violated, since the $2003 \mathrm{BiH}$ Criminal Code was applied, and not, in the appellant's opinion, the SFRY Criminal Code more favorable to it, which was valid at the time of the commission of the offenses. ${ }^{18}$ Constitutional Court of $\mathrm{BiH}$ rejected the appeal as unfounded, holding that the application of the Criminal Code of $\mathrm{BiH}$, in order to punish acts committed during an armed conflict, was allowed under Article 7, paragraph 2 of the European Convention, because these acts, at the time of execution, constituted criminal offenses under the "general legal principles recognized by civilized peoples". ${ }^{9}$

However, after using the last effective remedy, Abdulahim Maktouf and Goran Damjanović filed appeals to the European Court of Human Rights in Strasbourg, which, unlike the Constitutional Court of $\mathrm{BiH}$, concluded that retroactive application of the Criminal Code of $\mathrm{BiH}$ from 2003, when a criminal offense of War Crimes against Civilians is concerned, is contrary to Article 7 of the European Convention. ${ }^{20}$

Acting on the aforementioned judgment, although the European Court did not consider the application of the law in relation to other war crimes, the Constitutional Court of $\mathrm{BiH}$ also applied the prohibition of retroactivity to other, most serious crimes, including genocide. This resulted in the large number of convicts' appeals now adopted by the Constitutional Court of $\mathrm{BiH}$, and the fact that, after having taken that legal understanding, Genocide can now be sentenced to a maximum of 20 years imprisonment for the gravest war crimes, while Crimes against Humanity, which by nature is less grave, as a maximum, is punishable by up to 45 years in prison.

${ }^{18}$ The Court of Bosnia and Herzegovina sentenced Maktouf with the mildest sentence in the 2003 Criminal Code, five years in prison. However, under the 1976 Criminal Code, he could have been be sentenced to one year in prison.

${ }^{19}$ Constitutional Court of BiH, Appeal No: AP-1785/06, Decision on Admissibility and Merits of 30 March 2007.

${ }^{20}$ European Court of Human Rights, Maktouf and Damjanovic v. Bosnia and Herzegovina, Appeals Nos 2312/08 and 34179/08, Judgment of the Grand Chamber from 18 July 2013. 
It was in the decision in the Maktouf case, from March 2007, that the Constitutional Court of Bosnia and Herzegovina found that the application of various criminal laws at the state and entity levels seriously violated the rule of law and the principle of equality before the law, which will certainly continue to be a challenge in the prosecution of war crimes in Bosnia and Herzegovina. ${ }^{21}$

\section{Work on "Category A" cases}

According to Joanna Korner (2016), one of the main concerns is the efforts of the BiH Prosecutor's Office to produce favorable results in a statistical sense, by working on simpler cases, at the expense of prosecuting high-ranking perpetrators, and the fact that there is no policy within the Prosecution, which would serve for determining priority cases or criteria for case conclusion.

In the light of the above, the OSCE in its observation instructed the Prosecutor's Office of $\mathrm{BiH}$ to prioritize work on the most complex cases in accordance with the objectives and guidelines of the Revised National War Crimes Strategy (hereinafter: Revised Strategy) and to allocate sufficient resources, since the Revised Strategy provides for the processing of the most complex and priority cases before the Court and the Prosecutor's Office of $\mathrm{BiH}$, and other cases before the courts at the entity and Brcko District level by the end of $2023 .{ }^{22}$

Thus, the Revised Strategy foresees a deadline by the end of 2023. However, such a solution, as well as the concept of the Strategy, did not meet with the approval of the victims' families and their associations, who assessed that it did not again identify priority cases and cases that would have deployed within BiH's judicial system, which, in their view, will not contribute to effectively ending the processing of war crimes in $\mathrm{BiH} .^{23}$

The root cause of this situation is related to the fact that the Prosecutor's Office of $\mathrm{BiH}$ does not often apply an adequate procedure for determining priorities. It does not adhere to the criteria prescribed in Annex "A" of the National War Crimes Strategy, which leads to the fact that the Court of $\mathrm{BiH}$ deals with numerous cases of less complexity, which satisfy the requirements for prosecution before the Entity Courts, which was also concluded in the 2016 Situation Analysis (Korner, 2016, p. 53).

\footnotetext{
${ }^{21}$ Constitutional Court of BiH, Appeal No: AP-1785/06, Decision on Admissibility and Merits from 30 March 2007. par. 83-89

${ }^{22}$ See more: OSCE, Delivering Justice in Bosnia and Herzegovina: Prosecution of War Crimes Cases 2005-2010. op.cit.

${ }^{23}$ Victim Associations, First prioritize and then adopt a new strategy for the prosecution of war criminals. Available from: -sa-then-adopta-new-strategy-to-prosecute-war-criminals. [9 May 2019].
}

A similar view is found in the Thematic Report on the Management of War Crimes Cases in the Prosecution of Bosnia and Herzegovina (OSCE, 2019). This report states that one-third of the indictments filed by the $\mathrm{BiH}$ prosecution in 2017 and 2018 could be judged to be less complex according to the complexity criteria contained in annex A of the War Crimes Strategy from January 2009 to June 2015 (hereinafter: Strategies) ${ }^{24}$. This situation is worrying and has a very negative impact on the efficient use of available resources in state-level judicial institutions. The report also states that the Prosecutor's Office of $\mathrm{BiH}$ does not take measures that would substantially address these issues..$^{25}$

\section{Interpretation and application of complexity criteria}

Among the primary obstacles that have made it difficult to achieve the goals of the Strategy to the full extent is the uneven distribution of cases between the state and entity levels and the Brcko District of $\mathrm{BiH}$, all related to the inconsistent interpretation of the complexity criteria of the State Strategy. ${ }^{26}$

In January 2016, the Strategy Implementation Supervisory Body published a report that made a recommendation to transparently review the criteria for selecting and identifying priority cases, and the need to distinguish between priority cases and those falling into other categories (Komer, 2016, 23, par. 67).

According to a 2019 OSCE report, when it comes to indictments qualifying as war crimes, almost half of them could have been referred to the entity and Brcko District prosecutors' offices because of the nature of the crimes and the forms of culpability accused persons are charged of.

\footnotetext{
${ }^{24}$ National War Crimes Processing Strategy. Available from: http:// www.mpr.gov.ba/userfiles/file/Projekti/Drzavna\%20strategije $\% 20$ za\%20rad\%20na\%20predmetima\%20RZ.pdf

${ }^{25}$ Ibid. op.cit., p. 13.

${ }^{26}$ According to the OSCE, in the period between 2009 and 2017, in accordance with the mechanism for the transfer of cases envisaged by the Strategy, 480 less complex cases were transferred from the state level to the Entity and Brcko District of $\mathrm{BiH}$ level courts, with the largest number of these cases being transferred in 2012. However, the reduction of the total number of unresolved complex cases by their submission and termination before the Court of $\mathrm{BiH}$ does not reflect that number, as the Court of $\mathrm{BiH}$ has taken over 262 cases from the courts in the Entities and the Brcko District of $\mathrm{BiH}$ in the same period. (See more: OSCE, September 2018, Observations on the National War Crimes Processing Strategy and the Draft Revision of 2018, including the "Category A" Rules of the Road, Thematic Report).
} 
The burden of responsibility under this report lies with the Prosecutor's Office of $\mathrm{BiH}$, which does not carry out its duties under the Strategy in an efficient manner to ensure that the most complex and serious war crimes cases are prosecuted before the Court of $\mathrm{BiH}$. In particular, the mission noted that the Prosecution of Bosnia and Herzegovina inconsistently interpreted and applied the criteria for assessing the complexity of cases.Given that the primary criteria were applied too rigidly, without considering other important circumstances, the Revised Strategy envisaged redefined complexity criteria based on on the basis of a dual assessment of gravity in relation to the crime and the role of the perpetrator. In this way, special emphasis was placed on the organized form of committing war crimes or the command responsibility of the perpetrator, as a criterion of complexity.

\section{Regional dialogue and cooperation}

The results so far in the processing of war crimes in $\mathrm{BiH}$ have highlighted the need to establish mechanisms which would aim at strengthening regional dialogue and cooperation in war crimes cases. Although, on 31 January 2013, the Prosecutor's Office of BiH and the War Crimes Prosecutor's Office of the Republic of Serbia signed the Protocol on cooperation in the prosecution of war criminals, crimes against humanity and genocide, and on 3 June 2013. The same protocol was signed with the State Attorney's Office of the Republic of Croatia ${ }^{27}$.

Such cooperation was limited to technical dialogue and the exchange of good practices in the prosecution of war crimes, while the crucial objectives and practical implementation of such protocols were largely absent. ${ }^{28}$

\footnotetext{
${ }^{27}$ Protocol on Cooperation in Prosecution of War Crimes, Crimes against Humanity and Genocide, concluded between the Prosecutor's Office of $\mathrm{BiH}$ and the War Crimes Prosecutor's Office of the Republic of Serbia on 31 January 2013. Available from: http://tuzilastvobih.gov.ba/files/docs/Protokol-bos.pdf [9 May 2019] and Protocol on Cooperation in Prosecution of War Crimes, Crimes against Humanity and Genocide, concluded between the Prosecutor's Office of BiH and the State Attorney's Office of the Republic of Croatia on 3 June 2013. Available from: http:/tuzilastvobih.gov.ba/ files/docs/Protokol_Croatia,_BIH.pdf, [9 May 2019].

${ }^{28}$ The Protocol provides the exchange of information and evidence relating to crimes committed in the territory of both States when the suspects have the nationality or residence in the other Contracting State, as well as notification of the stage at which the case is, after the exchange of information and evidence. In addition, within three months of its signature, the signatories must notify each other of active cases against nationals of the other Contracting Party, which should finally overcome the practice of conducting parallel investigations (Article 3 of the Protocol).
}

An illustrative example is the Novak Đukic case, in which, after the final termination of the proceedings, the convicted person did not respond to the summons to serve his sentence in $\mathrm{BiH}$.

An international warrant was issued for him, after which the Court of $\mathrm{BiH}$ sent a request to Serbia for the recognition and enforcement of a final criminal conviction, in order for Đukic to serve his sentence in Serbia. ${ }^{29}$ However, the Trial Panel of the War Crimes Chamber of the Higher Court in Belgrade, in proceedings in recognition of the judgment of the Court of Bosnia and Herzegovina in the past three years, adjourned its sessions more than ten times, due to the convicted person's poor health. In addition, pursuant to the pleadings of Novak Đukic's defense, the acting court asked the Court of $\mathrm{BiH}$ for the entire file, to examine whether the convicted person had a fair trial, which the Court of $\mathrm{BiH}$ ultimately ceded. At the same time, Novak Đukić's team, at the Technical Survey Center of the Serbian Army in Nikinci, organized an experiment "Reconstruction of Crime at the Tuzla Gate", which resulted in the conclusion that the facts established in the final judgment of the Court of $\mathrm{BiH}$ against Novak Đukić were incorrect.

The mechanisms put in place to contribute to development of regional cooperation must be aimed at building trust between judicial institutions in the region, with the institutions having to respect and accept the facts established before the courts of other countries of the region, or to confirm the final judgments of these courts. Although the above example does not support this, the neighboring countries, and in particular Republic of Serbia, will in the future be further motivated to promote such cooperation, especially given that effective regional cooperation and good neighborly relations in the investigation and prosecution of war crimes, including the avoidance of conflicts of jurisdiction, are part of the formal conditions for Serbia's accession to the European Union. ${ }^{30}$

The aim of the research was to contribute to the assessment of the current situation regarding the prosecution of war crimes committed in $\mathrm{BiH}$ and to stimulate discussion on this topic, that is, the problems faced by the $\mathrm{BiH}$ judiciary in the processing of war crimes and possible solutions to overcome them.

\footnotetext{
${ }^{29}$ Case Information (X-KRŽ-07/394) on Novak Đukic are available on the official website of the Court of Bosnia and Herzegovina: http://www.sudbih.gov.ba/predmet/2472/show. [9 May 2019]. ${ }^{30}$ Negotiating positions for Chapter 23 - EU Common Position, p. 7, 22. Available from: http://www.mei.gov.rs/upload/documents/accessories/Programming_Positions/PG23\%20Community\%20Position\%20EU.pdf. [9 May 2019].
} 


\section{METHODS}

As a measuring instrument for the research, a questionnaire to collect data on the extent and phenomenology of war crimes in Bosnia and Herzegovina was used.

The questionnaire consists of two variables: the criminal report on the criminal offense; order to conduct an investigation; indictment; judgment dismissing the charge; acquittals; sentences of imprisonment; a conviction imposing a fine; a conviction ordering a suspended sentence; a conviction pronouncing a judicial reprimand; a conviction pronouncing a sentence of release, of which four variables were set aside for the purpose of this work.

Data were collected and analyzed for the period 2014-2018. Data collection was performed on two occasions. In 2017, data that were available so far were collected, and data for the last two years of interest in this research (2017 and 2018) were collected in the first half of 2019 by submitting questionnaires to the High Judicial and Prosecutorial Council of Bosnia and Herzegovina (hereinafter: Council). The Council maintains on-going databases. From the requested and obtained data for the period of five years (2012 to 2016), the data for 2014, 2015, and 2016 were first taken and subsequently, the survey was supplemented by the data for 2017 and 2018. In addition to this data, for the purppose of comparison, the data collected, sistematyzed, and published by the OSCE Mission in Bosnia and Herzegovina, in mid-2019, which are related to this issue, were also used in this paper. The data were processed by descriptive analysis, that is, the frequency distribution and percentages for the selected variables were determined, and the results presented graphically. In addition, a comparative analysis of the data according to the stages of criminal proceedings was done.

\section{RESULTS AND DISCUSSION}

\section{Representation of reported war crimes (by number of cases and persons)}

Chart 1 shows that during the researched period a total of 1,135 charges and reports of comitted criminal offences were filed ${ }^{31}$, which included 3,480 persons.

It is noticeable that the highest number of charges or reports $(281,889$ persons) were filed in 2015 , and this number has been steadily decreasing over the period under study, thus in 2018 there were a total of 177 charges and reports of criminal offenses against, also the least number of persons (278). The data also show that a total number of 542 charges or reports against 4,499 persons were transfered from 2013.

The data presented in Chart 1 show some important information regarding war crimes prosecutions in Bosnia and Herzegovina. Although the subject of research in this paper is the period twenty years after the end of the war (the commission of crimes), there are an extremely large number of charges/reports on war crimes committed. Especially notable is a large number of persons covered by these reports $(3,480)$. It can be observed that on average almost every charge/report covers three persons. A large number of charges/reports and persons involved, twenty years after committing crimes are a defeating fact for results of the work on the prosecution of war crimes, but also a danger for successful conduct and completion of these proceedings. According to Judge Corner in her report on state-level war crimes prosecutions in Bosnia and Herzegovina (Korner, 2016), the greatest danger lies in accessing suspects and witnesses, pointing to the fact that many of them have passed away, emigrated or forgotten events, and that they may have "false" memories. She also believes that repetitions of statements of these witnesses before different institutions and in different procedures could lead to some inconsistencies in their statements and could be used by defense of the suspects/accused in the later stages of the proceedings to indicate unreliability of witnesses. Important information we obtain from Chart 1 shows that the number of charges/reports and persons covered by them is decreasing, especially in the last two years of the observed period. This could be an indication that the identification of all war crimes cases is finally coming to an end.

\footnotetext{
${ }^{31}$ According to the laws on criminal procedure, charges are press by officials and responsible persons in legal entities and citizens, while reports on the committed crime are submitted by authorized officials who have appropriate powers within the police bodies.
} 


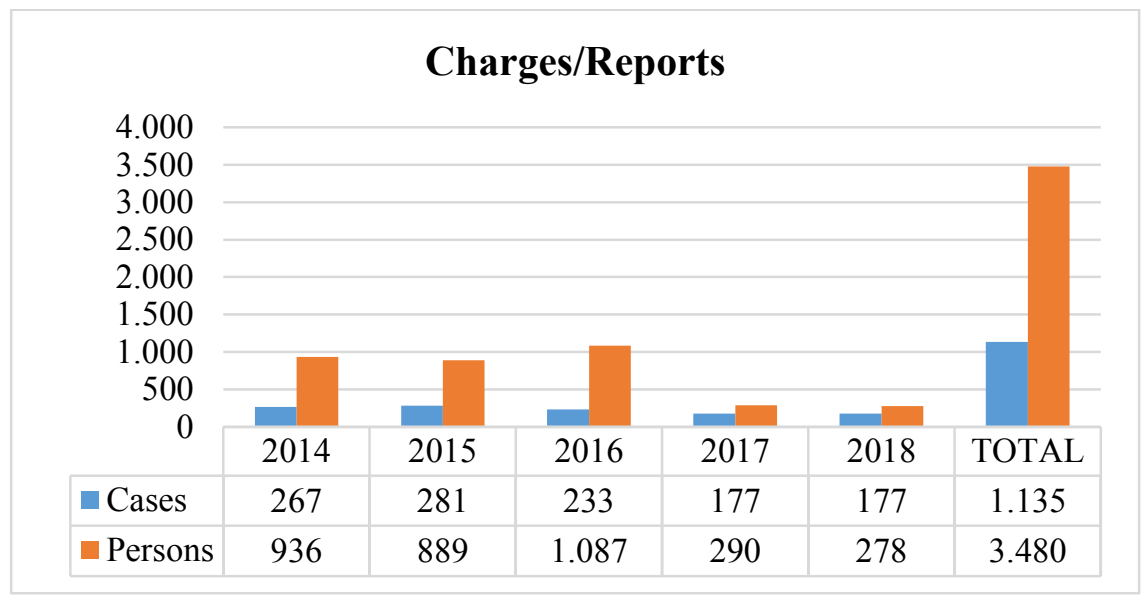

Chart 1. Charges and reports of committed war crimes (by years of research and total)

Representation of investigations initiated in war crimes cases (by number of cases and persons)

Chart 2 shows that during the investigated period, a total of 944 cases were ordered to be investigated against 2,701 persons. It is noticeable that the highest number of investigations (993, against 244 persons) was ordered in 2014, and this number is constantly decreasing in the investigated period, so that in 2017 there was the least number of ordered investigations (140 cases, against 229 persons), and slightly more In 2018 (155 cases, against 229 persons). The data we have show that 579 investigations against 2,037 persons were trasfered from 2013.
Bearing in mind that a total of 205 cases have been closed before the Court of $\mathrm{BiH}$ since its establishment until the end of 2018, the number of investigations conducted by Prosecutors' Offices in Bosnia and Herzegovina is worrying and represents a real danger of compliance with all the deadlines set so far in regard to completion of war crimes cases. In this respect, it is possible to agree and support the recommendations made by the OSCE Mission to Bosnia and Herzegovina in its Thematic Report on the Management of War Crimes Cases before the Prosecution of Bosnia and Herzegovina" (OSCE, 2019). According to these recommendations, it is necessary to share the burden of prosecuting war crimes within the judicial system in Bosnia and Herzegovina, while respecting the criteria for assessing the complexity of cases as defined by the National War Crimes Processing Strategy. ${ }^{32}$

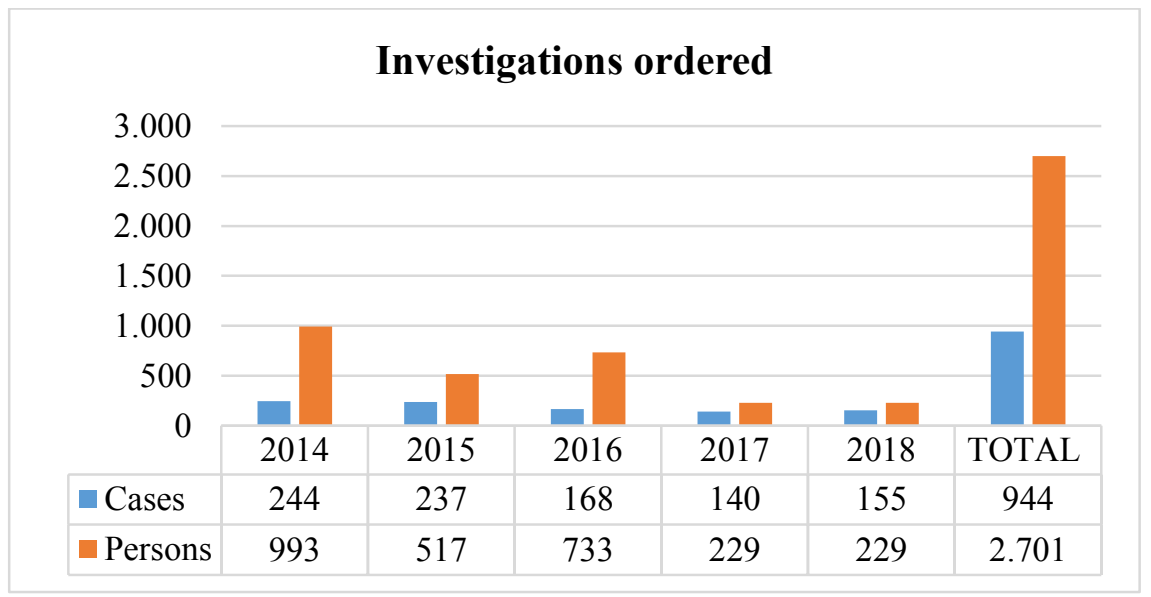

Chart 2. Ordered investigations on war crimes committed (by years of research and total) 
Representation of indictments in war crimes cases (by number of cases and persons)

Chart 3 shows that a total of 366 indictments were filed during the period under review and 720 persons were indicted. The highest number of indictments (102 against 211 persons) were filed in 2014, and this number is constantly decreasing in the investigated period, so that in 2018, 46 indictments were filed against 66 persons.

It is obvious that during the observed period the number of indictments was reduced, so at the end of this period twice less indictments were filed compared to the beginning of the observed period. The reasons for this deterioration in the performance of prosecutors' offices in Bosnia and Herzegovina in war crimes cases need to be investigated in detailals, and it is certain that some of them are also recognized in the OSCE Thematic Report (prosecutors' professional qualifications, the organization of the Special Prosecution Division, etc.).

The purpose of this paper was to present the number of confirmed indictments, in order to compare the indictments raised and confirmed, and to demonstrate the quality of the indictments submitted for confirmation. However, this was not possible; given that the data obtained in the second phase of the survey (data for 2017 and 2018) do not contain this information. Why this record is not kept is a question that should be investigated. Data for the first three years of the observed period show that just under $90 \%$ of the indictments are confirmed, which is certainly not commendable for the prosecutors who file such indictments.

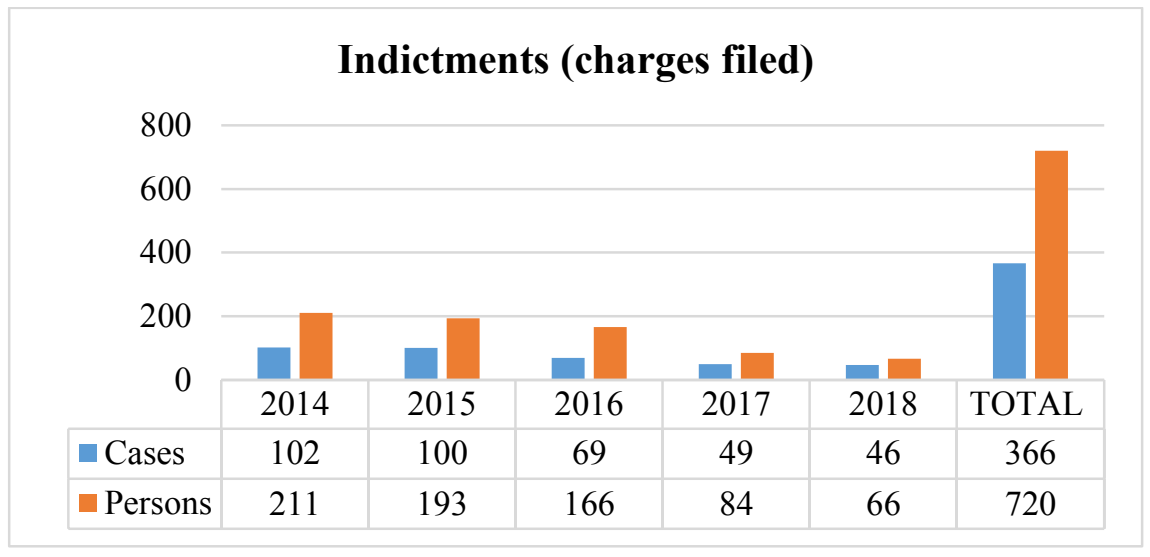

Chart 3. Indictments for committed war crimes (by years of research and total)

\section{Representation of convictions in war crimes cases (by number of cases and persons)}

Chart 4 shows that during the period under review, a total of 254 war crimes judgments were issued by all courts in Bosnia and Herzegovina, which involved a total of 434 persons. The highest number of judgments (61, covering 89 persons) were issued in 2015 , and thereafter the number of judgments rendered by courts in war crimes cases has steadily decreased. The fewest rulings were made in 2018, 48, and those referred to 98 people.

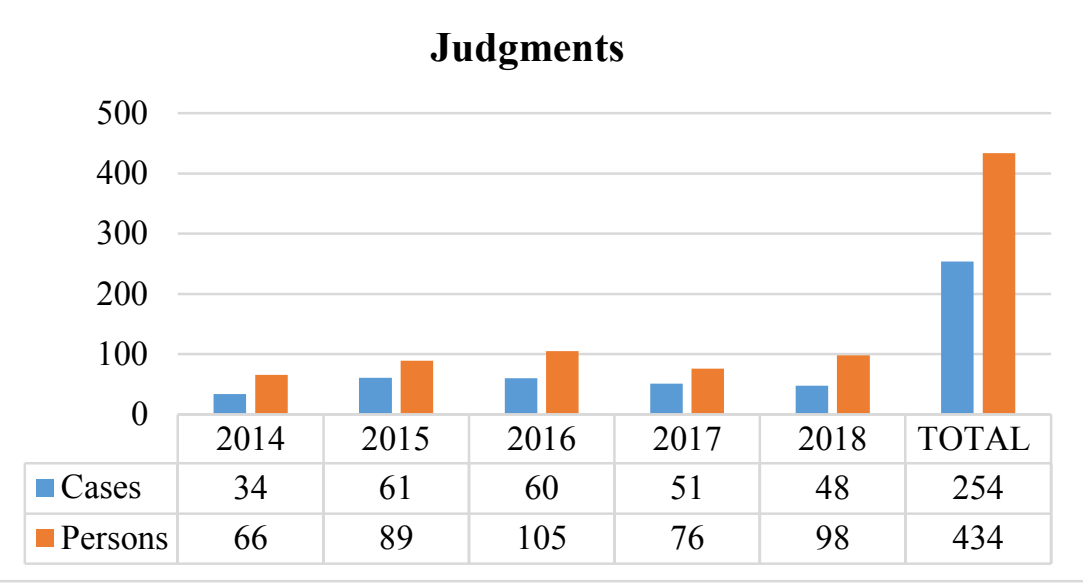

Chart 4. Judgments for committed war crimes (by years of research and total) 
Chart 5 shows that during the period under review, a total of 188 convictions and 66 acquittals were rendered by all courts in Bosnia and Herzegovina. Thus, more than $26 \%$ of the acquittals were rendered. Most acquittals were made in 2014 (32\%) and least in 2018 (17\%).

The OSCE Mission to Bosnia and Herzegovina finds reasons for such results, in its thematic report, in inconsistencies in the testimony of witness- es and in the absence of corroborating evidence to support the existence of the essential elements of the crimes charged and the evidence to support the form of their guilt. ${ }^{33}$ Such a finding could also be accepted when it comes to processing war crimes at other levels (outside the Court of $\mathrm{BiH}$, which was analyzed in the Thematic Report), but nevertheless, a more specific and accurate view would require special research.

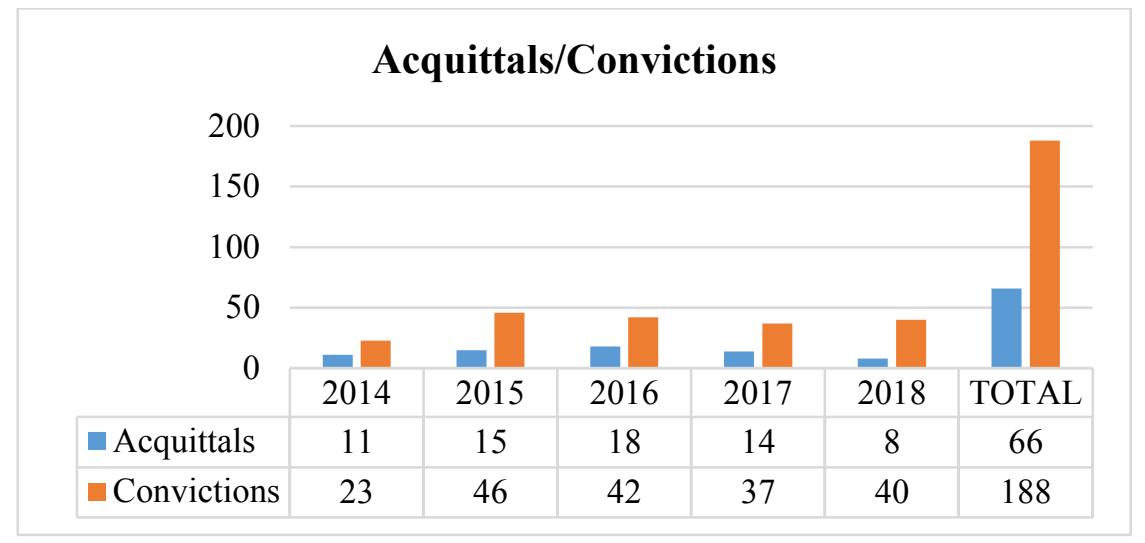

Chart 5. Structure of judgements for war crimes committed (by years of research and total)

Comparative analysis of war crimes cases with respect to the stages of the proceedings

\section{Comparison of the volume of reported war crimes and investigations initiated (by number of cases)}

Chart 6 shows the ratio of the number of reported crimes, that is, reports on war crimes committed and investigations initiated. It shows that the highest number of investigations (91.38\%) was initiated on charges/reports in 2014, and later decline followed, which in 2016 resulted in the smallest percentage (72.1\%) of investigations initiated on filed charges/ reports. The chart also shows that the total percentage of investigations initiated by all charges/reports in the observed period is $83.17 \%$.

It could be concluded that this is a rather high percentage of investigations initiated in relation to the number of charges/reports submitted during this period, which again indicates that these are high-quality reports / reports that contained the basis of suspicion required for prosecutors to initiate an investigation.

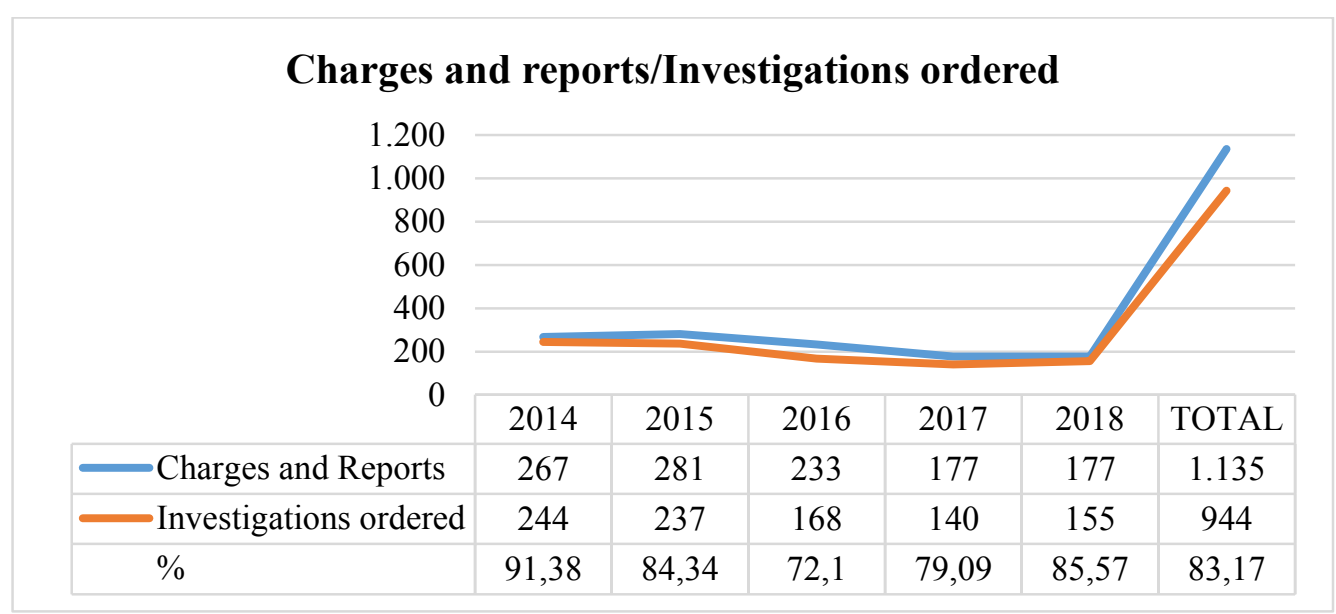

Chart 6. Comparison of filed charges reports and ordered investigations (by years of research and total)

\footnotetext{
${ }^{33}$ OSCE, War Crimes Case Management at the Prosecutors Office of Bosnia and Herzegovina (Thematic report), op.cit., pp. $7-10$
} 
Comparison of the volume of investigations initiated and indictments raised (by number of cases)

Chart 7 shows the ratio of the number of investigations initiated and indictments filed in war crimes cases over the reference period. It shows that the highest number of indictments $(42.19 \%)$ in relation to the number of investigations initiated was recorded in 2015, and that there is a constant decline thereafter, and that in 2018 the least nember of indictments were filed in relation to the number of investigations initiated (29.68\%). The graph also shows that the total percentage of indictments raised in relation to the investigations initiated in the observed period is only $38.77 \%$.

The very low percentage of indictments raised in relation to the investigations initiated can be attributed to various causes, which may include some objective ones such as the complexity of the case, the long distance between the commission of the crime and the time of the investigation, the unavailability of the suspects and witnesses of these crimes, etc. It can be argued with certainty that there are some subjective reasons that will not be presented here, but the need to further investigate this problem, identify any shortcomings and take action to remedy them, should be pointed out.

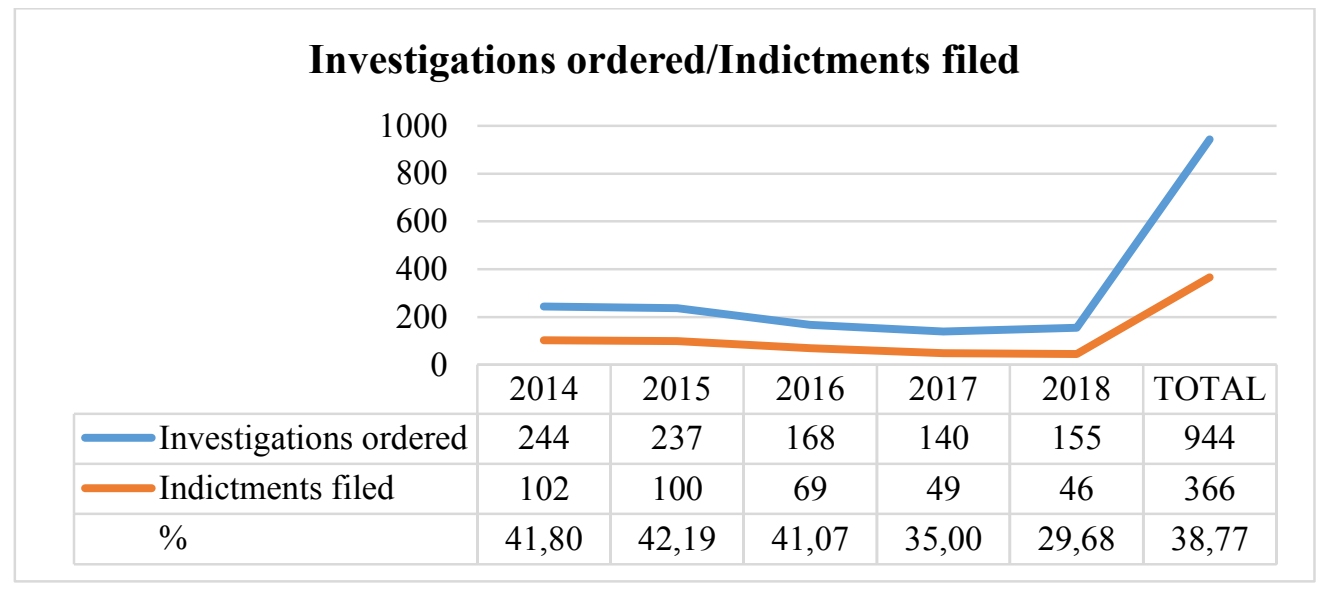

Chart 7. Comparison of ordered investigations and indictments (by years of research and total)

Comparison of the volume of indictments and convictions (by number of cases)

Chart 8 shows the ratio of the number of indictments filed and convictions in war crimes cases over the observed period. By far the lowest percentage of convictions in relation to the number of indictments filed in the observed period $(22.55 \%)$ was recorded in 2014. Thereafter, there was an increase and at the end of the observed period (2018), a percentage of $86.96 \%$ of convictions was recorded in relation to the number of indictments filed. In the observed period, a total of $51.37 \%$ of convictions were issued in relation to the number of indictments filed.

It is obvious that almost half of the cases brought before the competent court in the observed period were closed without conviction.

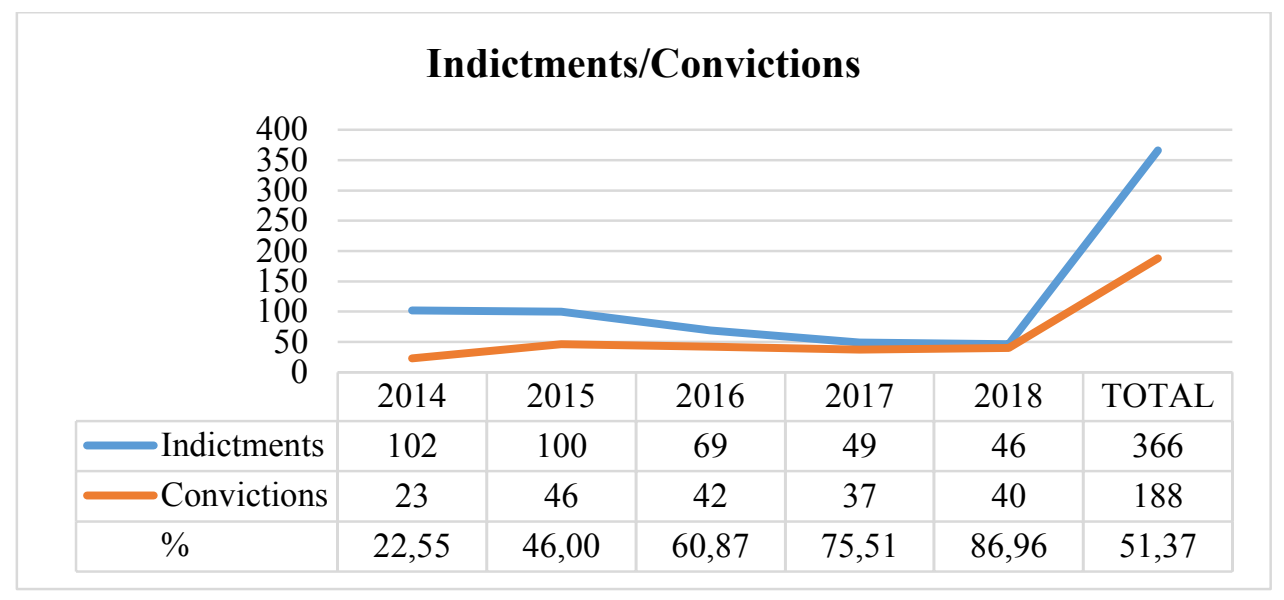

Chart 8. Comparison of indictments and convictions (by years of research and total) 


\section{Comparison of ordered war crimes investigations and convictions (by number of cases)}

It seems interesting to compare ordered investigations $^{34}$ in war crimes cases and convictions in the observed period, as shown in Chart 9. It can be seen that the lowest number of convictions in relation to the number of investigations initiated happened in 2014, only $9.43 \%$, and that it rose to a maximum of $26.43 \%$ in 2017. In total, in the observed period only $19.92 \%$ of cases in relation to the number of investigations initiated, ended with a conviction, therefore, every fifth case.

This information is a very clear indication of the inefficiency of prosecutors dealing with war crimes in
Bosnia and Herzegovina, and a clear proof of the inadequate use of available resources (human, material, financial, etc.) in war crimes prosecutions.

The data shows that the concerns and perceptions expressed by citizens, as well as by some domestic and international institutions regarding the effectiveness of prosecutors' offices in prosecuting war crimes cases, are very justified.

This kind of information calls for action of all relevant individuals and institutions to react from their domain to overcome these poor results. The seriousness of the situation should be considered given the importance of prosecuting war crimes committed in Bosnia and Herzegovina for the reconstruction, both by war and these crimes, of a devastated Bosnian society.

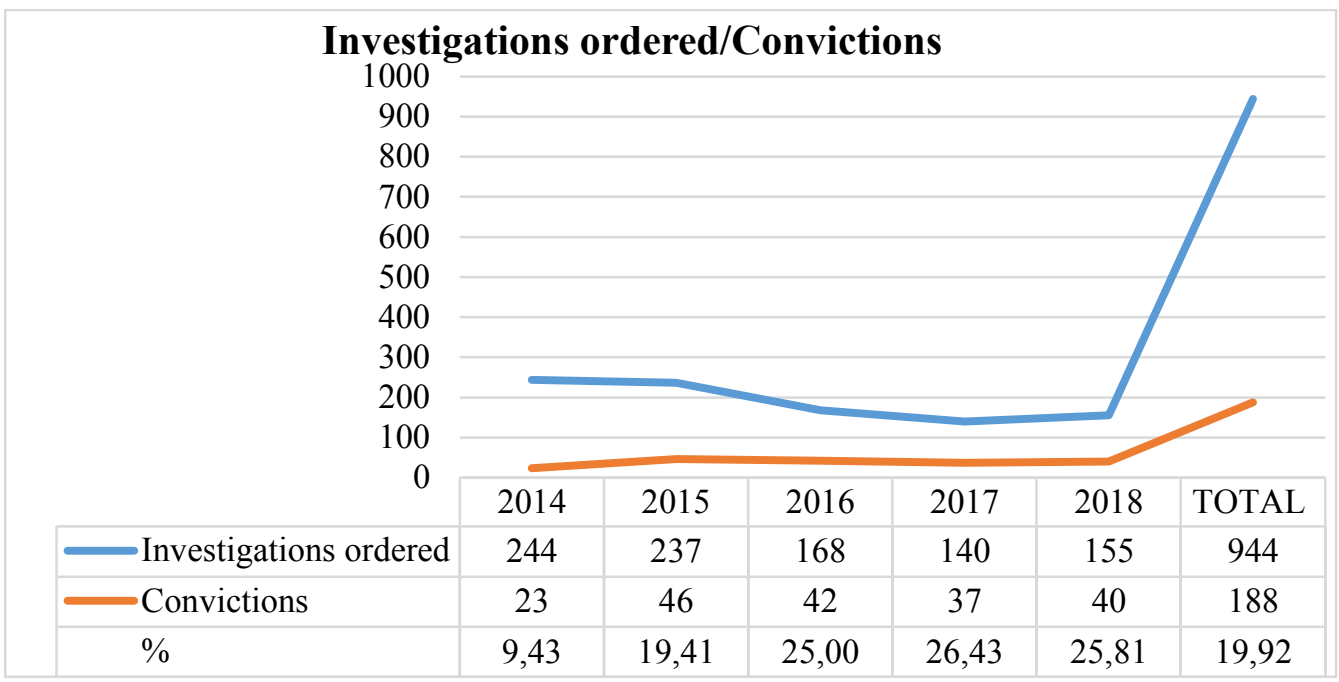

Chart 9. Comparison of ordered investigations and convictions (by years of research and total)

\section{CONCLUSION}

During the 1992-1995 armed conflict in the territory of Bosnia and Herzegovina, serious, systematic and mass violations of international humanitarian law occured, resulting in various serious violations of fundamental human rights and freedoms, including murders, the persecution of the population, mass forced detentions, brutal rapes, as well as robberies of private and industrial establishments, therefore, it is reasonably concluded that the actual and final scale of the crimes committed will never be fully known.

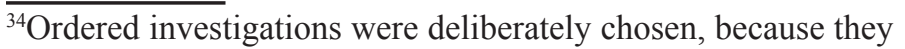
already show and are fully the result of the activities of competent, expert and authorized bodies (Prosecutor's Offices) and show that in their opinion there was a basis for suspicion of the commission of criminal offenses and that since that time a number of institutions and persons were engaged in these cases.
}

The criminal prosecution and processing of war crimes committed in the territory of Bosnia and Herzegovina is the responsibility of several courts of different levels, namely the ICTY, courts in Bosnia and Herzegovina, as well as the courts of other countries, in accordance with the principle of universal jurisdiction.

With the establishment of the ICTY, the tradition of impunity for war crimes was undoubtedly broken, and all persons were held accountable, regardless of their position, which made it possible to identify key facts regarding crimes committed in $\mathrm{BiH}$ and greatly influenced development of international criminal and humanitarian law as a whole.

However, the fact that is justifiably worrying is that even after 24 years since the end of the war, judicial authorities in Bosnia and Herzegovina have not completed the prosecution of even the highest priority cases. 
This is due, among other things, to the judicial authorities' intentions to achieve statistical results, failure to follow the directions and guidelines of the Strategies, implementation of various laws at the state and entity levels, as well as limited regional cooperation and dialogue, in which the practical implementation of signed agreements and protocols is completely absent so far. Therefore, a Revised Strategy has been drafted, which envisages the processing of the most complex and priority cases before the Court and the Prosecutor's Office of $\mathrm{BiH}$, and other cases before the Entity and Brcko District courts before the end of 2023. However, while it is aimed solely at eliminating the challenges of war crimes prosecutions so far, as well as defining deadlines and precise instructions for implementing the war crimes target strategies so far, the revised strategy has not yet been adopted. The prosecution of war crimes committed in Bosnia and Herzegovina is very important for the reconstruction of the devastated Bosnian society, both by war and by these crimes. The results of the empirical research show that the number of reports of these crimes is decreasing, that almost one thousand cases involving almost three thousand suspects/accused persons are in the process, and that the burden of prosecuting these cases needs to be shared within the $\mathrm{BiH}$ judicial system, as envisaged by the War Crimes Strategy.

It is noticeable that in the observed period slightly less than $40 \%$ of the investigations initiated were terminated by the indictment, and that there was a downward trend in the number of indictments raised. Furthermore, just over half of the indictments result in a conviction, which is certainly small percentage and it is worrying.

The inefficiency of the $\mathrm{BiH}$ judiciary is even more evident when comparing data on the number of investigations initiated and the number of convictions. These data show that only every fifth case in which an investigation is initiated ends in a conviction.

Empirical research data show that the concerns and perceptions expressed by citizens, as well as by some domestic and international institutions, regarding the effectiveness of prosecutors' offices in prosecuting war crimes cases are very justified. Such data call for action by all relevant individuals and institutions to undertake activities in their own domain in order to advance this process and bring it to the level it deserves given the importance for the overall $\mathrm{BiH}$ society.

\section{REFERENCES}

Babić, M. et al (2005). Komentari krivičnog/kaznenog zakona BiH. $\mathrm{CE} / \mathrm{EC}$, Sarajevo.

Babić, M. \& Marković, I. (2007). Krivično pravo - posebni dio (drugo mdifikovano izdanje). Banja Luka: Faculty of Law.
Comments of the Criminal Code of the Socialist Federal Republic of Yugoslavia 1978. Belgrade: Savremena administracija.

Criminal Code of Bosnia and Herzegovina, Official Gazette of Bosnia and Herzegovina No. 3/2003, 32/2003 - ratified, 37/2003, 54/2004, 61/2004, 30/2005, 53/2006, 55/2006, 8/2010, 47/2014, 22/2015, 40/2015 and 35/2018).

Degan, V.Đ., Pavišić, B. \& Beširević, V. (2011). Međunarodno $i$ transnacionalno krivično pravo. Belgrade: Union Univrsity, Faculty of Law.

Dimitrijević, V., Hadži-Vidanović, V., Jovanović, I., Marković, Ž., \& Milanović, M., (2013). Haške nedoumice - Poznato $i$ nepoznato o Međunarodnom krivičnom tribunalu za bivšu Jugoslaviju, drugo izdanje, Belgrade: Belgrade Center for Human Rights.

Đurđić, V. \& Jovaševic, D. (2003). Međunarodno krivično pravo. Belgrade: Nomos.

Human Rights Council. (2008). Resolution 9/11: Right to the truth (24 September 2008). [Online]. A/HRC/RES/9/11. Available from: https://ap.ohchr.org/documents/E/HRC/ resolutions/A_HRC_RES_9_11.pdf.

Ivanišević, B. (2008). The War Crimes Chamber in Bosnia and Herzegovina: From Hybrid to Domestic Court, The International Center for Transitional Justice.

Josipović, I. (2007). Ratni zločini - Priručnik za praćenje suđenja. Osijek: Center for peace, nonviolence and human rights.

Jovaševic, D 2004, Sistem odgovornosti i kažnjivosti za međunarodna krivična dela, U: Radovanović, D, XVI Seminar prava: Teški oblici kriminala. Belgrade: Institute of Criminological and Sociological Research.

Karović, S. year 21st. (2012), Kaznena djela protiv čovječnosti $i$ međunarodnog prava. Polic. Sigur., 4, Zagreb.

Korner, J. (2016). Procesuiranje ratnih zločina na državnom nivou u Bosni i Hercegovini, Analiza stanja.

Kukić, S, et al (2019). Sistem ranog upozoravanja specijalno izdanje - Pravda i istina u BiH iz perspektive javnosti (15 april 2019). Available from: www.undp.ba/download.aspx?id=355.

Law on the Court of BiH (consolidated text), Official Gazette of $\mathrm{BiH}$ No. 49/09, Article 1.

Mahmutović, Dž. (2011). Ratni zločini u Bosni i Hercegovini Kažnjavanje i reparacija - doctoral thesis, Faculty of Law, University of Tuzla, Tuzla.

Marković, I. (2010). Zločin protiv čovječnosti u Krivičnom zakonu Bosne i Hercegovine, Annual of the Faculty of Law of University of Banja Luka, No. 31/32, Banja Luka.

Mrvić-Petrović, N. (2008). Krivično pravo - opšti i posebni deo (peto izdanje), Union University, Faculty of Law, Belgrade.

National War Crimes Processing Strategy. Available from: http:// www.mpr.gov.ba/userfiles/file/Projekti/Drzavna\%20strategije\%20za\%20rad\%20na\%20predmetima\%20RZ.pdf.

Novoselec, P. (2003). Temeljne crte novele Kaznenog zakona, $H r$ vatski ljetopis za kazneno pravo i praksu, 10 (2), Zagreb.

OSCE (2011). Achieving Justice in Bosnia and Herzegovina: Prosecution of War Crimes Cases 2005-2010.

OSCE (2019). War Crimes Case Management at the Prosecutor's Office of Bosnia and Herzegovina (Thematic Report), Sarajevo.

OSCE (2013). War Crimes before Domestic Courts, Belgrade.

OSCE (September 2018). Observations on the National War Crimes Processing Strategy and the Draft Revision of 2018, including the "Category A" Rules of the Road, Thematic Report). 
Popović, D. (2009). Vodič kroz tranzicijsku pravdu u Bosni $i$ Hrcegovini, UN Development program, Sarajevo.

RDC (2019). Human Losses 1991-1995. Available from: http:// www.idc.org.ba/index.php?option=com_content\&view $=$ section\&id=35\&Itemid $=126 \&$ lang $=$ bs

Seizović, Z. (2008). Međunarodno javno pravo - zbirka eseja, Zenica: University of Zenica.
Simović-Hiber, I. (2007). Sistem rasprava o ideji vladavine prava, osnovama krivičnog zakona, pojmu zločinacke grupe i internacionalizaciji krivičnog prava. Belgrade: Institute of Criminological and Sociological Research.

Škorić, M. (2005). Mješoviti međunarodni kazneni sudovi. Rijeka: Collection of works of the Faculty of Law of the University of Rijeka, 2. 